\title{
ANALISIS ENTREPRENEURIAL LEADERSHIP DAN HAMBATAN PERTUMBUHAN USAHA DI UMKM PENGOLAHAN TAHU "RDS" SINGOSARI MALANG
}

\author{
Aris Wahyu Tristanto, Universitas Negeri Malang \\ ariswahyu134@gmail.com \\ Ludi Wishnu Wardana, Universitas Negeri Malang \\ ludi.wishnu.fe@um.ac.id
}

\begin{abstract}
ABSTRAK
Penelitian ini dilakukan dengan tujuan untuk menggambarkan entrepreneurial leadership UMKM Tahu "RDS" dan gambaran tentang hambatan yang dialami oleh UMKM Tahu "RDS". Penelitian ini menggunakan rancangan penelitian deskriptif kualitatif yang bertujuan untuk memperoleh informasi-informasi yang ada pada saat ini, dan kemudian berupaya untuk mendeskripsikan, mencatat dan menginterpretasikan informasi tersebut. Metode pengumpulan data yang digunakan adalah wawancara, observasi dan dokumentasi. Jenis penelitian kualitatif ini adalah studi kasus (case study). Hasil peneltian yang didapat adalah kondisi entrepreneurial leadership dari pimpinan UMKM Tahu "RDS" secara umum baik karena beliau mampu memotivasi karyawan dengan baik, memiliki gambaran tentang usaha dimasa depan, mampu membaca peluang-peluang dengan baik, aktif mencari ide baru, gigih dalam menjalankan usahanya dan hambatan yang dihadapi oleh UMKM Tahu "RDS" bisa diatasi dengan baik oleh pimpinan UMKM tahu RDS tersebut.
\end{abstract}

Kata Kunci: Entrepreneurial Leadership, Hambatan Pertumbuhan Usaha.

\begin{abstract}
This research was conducted to describe the entrepreneurial leadership of SMEs Tofu "RDS" and description about the obstacles experienced by SMEs Tofu "RDS". This research uses descriptive qualitative research design that aims to obtain the information available at this time, and then attempt to describe, record and interpret the information. Data collection methods used were interviews, observation and documentation. This type of qualitative research is case study. The result of the research is the condition of entrepreneurial leadership from the leadership of SMEs Tofu "RDS" is generally good because he is able to motivate employees well, have a picture of the future effort, able to read opportunities well, actively seeking new ideas, persistent in running their business And barriers faced by SMEs Tofu "RDS" can be overcome well by the leadership of SMEs Tofu RDS.
\end{abstract}

Keywords: Entrepreneurial Leadership, Barriers To Business Growth. 


\section{PENDAHULUAN}

Usaha Mikro Kecil dan Menengah (UMKM) adalah sebuah istilah yang mengacu ke jenis usaha kecil yang memiliki kekayaan bersih paling banyak Rp200 juta tidak termasuk tanah dan bangunan tempat usaha. Menurut Tambunan (2012:11) UMKM adalah unit usaha produktif yang berdiri sendiri, yang dilakukan oleh orang perorangan atau badan usaha disemua sektor ekonomi. UMKM diatur berdasarkan UU Nomor 20 tahun 2008 tentang Usaha Mikro, Kecil, dan Menengah. UMKM pada negara berkembang, termasuk di Indonesia memiliki peran dalam meningkatkan perekonomian. UMKM menyumbang pembangunan dengan menciptakan kesempatan kerja, dan menyediakan fleksibilitas kebutuhan serta inovasi dalam perekonomian secara keseluruhan.

Sumber Daya Manusia merupakan salah satu faktor yang sangat penting bagi sebuah perusahaan. Sumber Daya Manusia dapat dilihat dari dua aspek yaitu kualitas dan kuantitas. Aspek kualitas mencakup kemampuan SDM baik secara fisik maupun nonfisik/kecerdasan dan mental dalam setiap pekerjaan yang diembannnya. Sedangkan aspek kuantitas mencakup besarnya jumlah SDM yang tersedia. Sumber daya manusia juga menjadi penentu dalam perkembangan suatu perusahaan.

Peranan UMKM dalam perekonomian memang besar. Dalam berbagai kesempatan disebutkan bahwa UMKM benar-benar menjadi tulang punggung perekonomian, khususnya Indonesia. UMKM berkontribusi dalam pembangunan ekonomi dan penggerak peningkatan ekspor non migas. Kontribusi yang diberikan UMKM akan semakin besar dalam pembangunan ekonomi apabila dapat terus dikembangkan. Era globalisasi menyebabkan terjadinya perubahan-perubahan yang begitu cepat di dalam dunia bisnis dan menuntut organisasi untuk lebih mampu beradaptasi terhadap segala perubahan yang terjadi. Untuk mengantisipasi situasi yang demikian, pemimpin perusahaan dituntut untuk memiliki kemampuan menangani kompleksitas kompetisi, peraturan dan aturan baru pasar global. Organisasi membutuhkan kepemimpinan dan manajemen yang kuat agar efektivitasnya optimal (Robbins dan Judge, 2008: 49).

UMKM dapat berkembang tidak terlepas dari inovasi yang dilakukan oleh pemilik atau pemimpinnya. Menurut Prakoso (2005:45) Inovasi adalah suatu mekanisme perusahaan untuk beradaptasi dengan lingkungan yang dinamis, guna memajukan atau mengembangkan UMKM. Dalam memulai berbisnis seseorang harus berani mengambil resiko-resiko dan juga mempunyai cara untuk mengatasi atau menangani resiko tersebut.

UMKM RDS adalah salah satu UMKM tahu organik terbesar di Malang. UMKM tahu RDS berdiri pada tahun 2004, pemilik sekaligus pemimpin tahu RDS bernama Rudik, pada tahun 2001 tepatnya pada saat bapak Rudik duduk di bangku kelas 3 SMA, beliau memulai berinvestasi pada sebuah UMKM tahu, namun pada tahun 2003 usaha tersebut bangkrut dan di ambil alih oleh bapak Rudik, dan pada tahun 2004 Bapak Rudik resmi membuat pabrik tahu bernama RDS. UMKM RDS sendiri mempunyai 16 karyawan. Pendapatan UMKM RDS ini dalam satu bulan bisa mencapai 150 juta per bulan.

Saat ini UMKM tahu RDS menjadi pemimpin pasar dalam pengelolaan 
dan produksi tahu di Malang. Meskipun banyak pesaing yang sama UMKM RDS tetap menjadi produsen tahu terbesar di Malang. Dari penjelasan diatas bisa dilihat bahwa UMKM tahu RDS mampu menjaga eksistensinya, hal ini tidak luput dari pengelolaan manajemen yang baik dari pemilik atau pimipin UMKM tahu RDS tersebut. Dari persoalan diatas peniliti tertarik untul meneliti bagaimana pimpinan UMKM tahu RDS mengelola UMKM tahu RDS, karena banyak faktor yang biasanya menjadi kunci keberhasilan entrepreneur.

Entrepreneurial leadership adalah semua tentang gebrakan baru, melampaui apa yang sudah ada dan membantu menciptakan masa depan (Darling, Keeffe, dan Ross, 2007). Entrepreneurial leadership adalah pragmatis dan fokus terhadap pemecahan masalah dan penciptaan berbagai nilai pasar (Surie dan Ashley, 2008). Entrepreneurial Leadership menurut Gupta dan MacMillan (2004), adalah "Sebuah model kepemimpinan yang melibatkan gabungan konsep entrepreneurship, konsep entrepreneurial orientation, dan konsep entrepreneurial management, dengan konsep leadership". Dari pengertian beberapa ahli di atas peneliti menyimpulkan entrepreneurial leadership adalah kepemimpinan yang memimpin secara inovatif, terlibat penuh dalam bekerja, mampu melihat, dan memanfaatkan peluang dengan metode sendiri.

Menurut Tjandra dan Ardianti tahun 2013 yang mana entrepreneurial leadership yang dimaksud adalah sebagai entrepreneur yang bisa menciptakan perubahan dan pengembangan budaya kewirausahaan dan penggabungan proses-proses entrepreneur, serta inisiatif-inisiatif baru yang karena dengan adanya perubahan akan menjadikan perusahaan lebih berkembang dan berjalan mengikuti tren pasar yang berlaku.Seorang entrepreneur yang baik, harus bisa menjadi seorang pemimpin untuk mempengaruhi karyawan untuk melakukan sesuatu pekerjaan sehingga karyawan dapat memunculkan ide-ide serta kinerja terbaik dan seorang pemimpin juga harus dapat melakukan pendekatan efektif bagi para bawahannya agar karyawan dapat merasa dihargai dan secara tidak langsung mereka akan dapat memberikan kontribusi penuh terhadap perkembangan perusahaan. Dalam berwirausaha seseorang dituntut untuk memiliki entrepreneurial leadership karena didalam berwirausaha untuk memenangkan persaingan seorang pemimpin diwajibkan membuat inovasiinovasi baru serta mampu mengatasi hambatan-hambatan pertumbuhan usaha dengan baik dan tepat.

Hambatan-hambatan pertumbuhan usaha yang sering dihadapi oleh seorang entrepreneur biasanya berasal dari faktor internal dan eksternal. Faktor internal biasanya meliputi kemampuan manajerial dalam mengetahui tentang kondisi pasar, pengalaman usaha yang relevan, pengalaman dalam manajemen usaha kecil serta faktor internal meliputi lokasi dan jaringan dimana seorang seorang entrepreneurial leadership harus mengetahui seberapa tinggi pengaruh lokasi yang ditempati sekarang serta jaringan responden terhadap lingkungan sekitar usaha. Adapun faktor eksternal meliputi finansial, ekonomi dan teknologi, kejahatan dan korupsi, infrastruktur, kompetisi, tenaga kerja.

Maka dari itu dalam berwirausaha seorang pemimpin harus mempunyai jiwa entrepreneurial leadership untuk memecahkan persoalan dan mengembangkan usahanya, serta seorang pemimpin harus mampu mengatasi hambatan-hambatan yang terjadi maumpun yang akan terjadi dimasa datang. 
Begitu pula jiwa entrepreneurial leadership harus dimiliki oleh pemimpin UMKM tahu RDS dan bagaimana cara pemimpin mengatasi hambatanhambatan pertumbuhan usaha. Tujuan dari penelitian ini adalah untuk mengetahui jiwa entrepreneurial leadership pada pimpinan UMKM tahu RDS dan hambatan-hambatan di UMKM tahu RDS.

\section{METODE PENELITIAN}

Pendekatan yang digunakan dalam penelitian ini adalah pendekatan kualitatif deskriptif untuk mendeskripsikan entrepreneurial leadership dan kaitannya dengan hambatan-hambatan pertumbuhan usaha, dan upaya mengatasi hambatan-hambatan. Metode penelitian kualitatif deskriptif salah satu pendekatan yang juga disebut investigasi karena biasanya peneliti mengumpulkan data dengan cara bertatap muka langsung dan berinteraksi dengan orang-orang di lokasi penelitian yaitu pada pimpinan dan karyawan di UMKM pengolahan tahu "RDS

Jenis penelitian kualitatif ini adalah studi kasus (case study). Myers (2009) mendefinisikan case study sebagai penelitian yang menggunakan bukti empiris dari suatu atau lebih organisasi dan peneliti berusaha mempelajari masalah tersebut.

Lokasi penelitian bertempat pada UMKM tahu RDS di Desa Klampok RT IV/RW II Singosari, Kabupaten Malang. Peneliti memilih lokasi tersebut karena pimpinan di UMKM pengolahan tahu "RDS" mempunyai inovasi baru dibidang pengolahan tahu yaitu tahu organik.

Penelitian ini menggunakan dua macam sumber data untuk mendukung penelitian tentang Analisis Entrepreneurial Leadership dan Hambatan Pertumbuhan Usaha pada UMKM Pengolahan Tahu "RDS", yaitu:

Data primer adalah data yang diperoleh atau dikumpulkan langsung di lapangan oleh orang yang melakukan penelitian.Data primer ini disebut asli atau data baru. Data primer dalam penelitian ini adalah dari hasil observasi, dokumentasi,wawancara yang dilakukan kepada narasumber yaitu kepada pimpinan UMKM tahu RDS dan karyawan UMKM tahu RDS.

Data sekunder adalah data yang diperoleh atau dikumpulkan oleh orang yang melakukan penelitian dari sumber-sumber yang telah ada.Data ini biasanya, diperoleh dari perpustakaan atau dari laporan penelitian terdahulu.Data sekunder juga disebut data tersedia.

Metode yang peneliti gunakan untuk mengumpulkan data dalam penelitian ini melalui wawancara, observasi dan dokumentasi. Sementara analisis data kualitatif yang penulis lakukan sejak sebelum memasuki lapangan, selama dilapangan dan setelah selesai dilapangan. Dalam hal ini teknik analisis data model interaktif menurut Miles dan Huberman (2007) terdiri dari empat tahapan yang harus dilakukan oleh peneliti, yaitu pengumpulan data, reduksi data, display data, serta kesimpulan atau tahap verifikasi.

\section{HASIL PENELITIAN DAN PEMBAHASAN}

Berdasarkan hasil temuan penelitian, diketahui bahwa Bapak Rudik selaku pimpinan UMKM "RDS" menerapkan entrepreneurial leadership pada 
usahanya dengan baik. Berbeda dengan konsep kepemimpinan yang lain, entrepreneurial leadership cenderung lebih membutuhkan ambisi dalam meramal masa depan dan kemampuan mengenali pola-pola baru dalam membingkai tantangan dan meredam ketidakpastian tanpa menonjolkan sisi heroik dari leader (Gupta dkk, 2010). Entrepreneurial leadership memiliki 7 karakteristik, diantaranya adalah able to motivate, visionary, proactiveness, innovativeness, risk taking, achievement oriented, dan persistent (Fernald, 2005). Pimpinan UMKM "RDS" memiliki dan menerapkan ke-7 karakteristik tersebut dalam usahanya.

Pada indikator able to motivate yang digambarkan oleh kemampuan pimpinan yang mampu untuk menciptakan lingkungan kerja kondusif, dapat memacu semangat kerja karyawan agar dapat menghasilkan kinerja terbaik, serta dapat mengarahkan karyawan untuk bekerja sesuai keinginan pimpinan, Bapak Rudik selaku pemilik sekaligus pemimpin UMKM "RDS" menganggap karyawannya sebagai tim dan keluarga, beliau juga memberikan BPJS kepada mereka. Dengan demikian, Bapak Rudik mampu menciptakan lingkungan yang kondusif bagi para pekerja di UMKM "RDS". Selain itu, Bapak Rudik juga selalu mengajak para karyawan untuk berdiskusi mengenai proker-proker dan job desc yang sesuai terkait usaha produksi tahu. Melalui kegiatan diskusi tersebut, Bapak Rudik dapat memacu semangat kerja karyawan sehingga dapat bekerja dengan lebih baik lagi.

Visi dari UMKM "RDS" antara lain adalah menjadi perusahaan tahu terbaik di Indonesia, meningkatkan kualitas kehidupandan pendapatan berkelanjutan. Bapak Rudik memiliki rencana-rencana untuk usahanya di masa depan, yakni beliau ingin melakukan pengolahan tahu organik yang lebih lanjut seperti membuat produk-produk baru yang masih jarang/belum ada di pasaran. Berdasarkan hal tersebut, maka dapat dikatakan bahwa indikator entrepreneurial leadership yaitu visionary dimiliki dan diterapkan dengan baik oleh pimpinan UMKM "RDS". Hal ini didukung oleh penelitian yang dilakukan oleh Tjandra \& Ardianti (2013:2) menyatakan bahwa entrepreneurial leader mampu menggambarkan dan menjelaskan tentang masa depan usahanya, dimana dia dan orang-orang sekitarnya akan berada, serta seperti apa mereka kelak. Dengan demikian ia dapat memiliki keyakinan dan meyakinkan orang lain agar dapat mencapai tujuan bersama tersebut.

UMKM "RDS" merupakan UMKM pertama yang bergerak pada bidang produksi tahu organik di Malang. Pimpinan UMKM "RDS" memiliki kemampuan untuk melihat dan membaca peluang yang ada di pasar, sehingga beliau berinovasi untuk memproduksi tahu dengan menggunakan bahan baku kedelai organik yang mana inovasi ini belum pernah dilakukan oleh pengusaha yang lain khususnya di area Malang. Saat ini banyak orang yang hidup sehat dan memilih untuk hidup vegetarian sehingga Bapak Rudik beranggapan bahwa dengan memproduksi tahu organik adalah salah satu tindak lanjut yang menguntungkan atas peluang bisnis yang ada. Berdasarkan penjelasan tersebut, maka dapat dilihat bahwa indikator entrepreneurial leadership yakni proactiveness diterapkan oleh pimpinan UMKM "RDS". Penitian ini didukung dengan penelitian menurut Tjandra \& Ardianti (2013:2) seorang entrepreneurial leader dituntut untuk menjadi seorang yang peka terhadap perubahan, juga dituntui untuk mampu beradaptasi dengan cepat terhadap 
perubahan tersebut.

Seorang entrepreneurial leader harus memiliki kemampuan untuk innovativeness terhadap produk yang dihasilkannya. Dengan inovasi tersebut, maka akan membantu pengusaha untuk terus mempertahankan bisnis yang dimiliki. Pimpinan UMKM "RDS" sudah mempunyai rencana untuk membuat produk baru yaitu tahu bulat organik, dan dalam membuat produk baru Bapak Rudik akan berunding dengan karyawannya terkait proses produksi. Dalam berdiskusi dengan karyawannya Bapak Rudik selalu mendengarkan dan merundingkan setiap ide-ide atau masukan dari para karyawannya. Penitian ini didukung dengan penelitian menurut Tjandra \& Ardianti (2013:1) kemampuan untuk menghasilkan ide-ide yang baru juga harus dimiliki seorang entrepreneurial leader, kreatifitas dari seorang entrepreneurial leader datang dari kemampuannya melihat peluang dan dari realita yang ada sekalipun terkadang realita menunjukkan trem yang buruk, kemudian mengubahnya menjadi sebuah bentuk kerja yang nyata demi kebaikan.

Seorang entrepreneur harus berani dalam mengambil keputusan dan siap menghadapi risiko yang mungkin terjadi, dengan keberanian dalam menghadapi tantangan namun juga memperhatikan berbagai resiko menjadi salah satu faktor yang menunjang keberhasilan pengusaha. Bapak Rudik selaku pemilik UMKM "RDS" selalu memperhatikan resiko kerugian dengan cara membuat model ECM (Enterprise Content Management) yaitu terkait membuat, mengambil, dan menyusun informasi atas resiko atau kerugian yang mungkin terjadi, kemudian beliau akan memproses dan menggunakan informasi tersebut agar bisa mengatur rencana dan meminimalisir resiko yang mungkin terjadi. Penitian ini didukung dengan penelitian menurut Tjandra \& Ardianti (2013) Berani mengambil resiko, tidak takut untuk mencoba sesuatu yang masih belum pasti tingkat keberhasilannya, entrepreneurial leader tidak hanya berdasarkan insting atau naluri semata dalam mengambil resiko, tetapi itu semuanya telah diperhitungkan dengan baik sebelumnya.

Keberhasilan seorang pimpinan usaha tidak dapat dilepaskan dari hasil pencapaian usahanya. Pimpinan harus memberikan perhatian lebih dalam bisnis atau usaha yang digeluti untuk mencapai hasil yang maksimal, mampu mendelegasikan tugas dengan baik, dan mampu terjun langsung untuk mengawasi prosesnya. Sebagaimana Bapak Rudik selaku Pimpinan UMKM "RDS" , beliau memberikan perintah kepada karyawannya tidak setiap hari namun melalui sistem pengawasan langsung dengan maksud beliau akan memberikan perintah dan akan diawasi sekaligus diberikan arahan jika terjadi kesalahan. Namun jika ada produk baru yang akan diproduksi Bapak Rudik akan melakukan pengawasan yang cukup ketat agar hasil dari produk baru tersebut bisa maksimal. Penitian ini didukung dengan penelitian menurut Tjandra \& Ardianti (2013) Tidak dapat dipungkiri bahwa proses adalah suatu hal yang penting dalam suatu pekerjaan namun hasil dari proses tersebut tidak boleh diabaikan, entrepreneurial leader tidak hanya berfokus untuk menciptakan proses kerja yang efektif dan efisien, tetapi juga melihat kepada hasil yang dicapai serta proses evaluasi untuk hasil yang lebih baik dikemudian hari.

Seorang pemimpin usaha harus mampu bertahan dalam setiap tantangan yang ada dan tidak mudah menyerah pada keadaan. Pimpinan mempunyai 
berbagai hambatan yang harus dihadapi, misalnya daya tahan terhadap stres, gigih dalam melewati segala hambatan, dan tidak mudah berganti kerjaan saat ada tantangan. Sebagai pemilik sekaligus pimpinan UMKM "RDS" Bapak Rudik mengaku selalu ada hambatan dalam setiap usaha namun beliau menegaskan selama ini belum ada hambatan yang begitu berarti karena beliau selalu gigih dan jika mengalami stres atau depresi beliau akan meluangkan waktunya untuk keluarganya dan meliburkan para karyawannya karena kata beliau fokus merupakan hal yang sangat penting untuk menjadi pengusaha. Penitian ini didukung dengan penelitian menurut Tjandra \& Ardianti (2013) entrepreneurial leader juga adalah seorang yang gigih dalam memperjuangan yang menjadi apa impiannya. Keteguhan merupakan karakter yang lahir dari sikap ulet, yaitu kemampuan untuk tidak menyerah apabila mengalami kegagalan.

Berdasarkan hasil temuan peneliti di UMKM "RDS", terdapat beberapa hambatan yang terjadi pada UMKM tersebut. Menurut Olawale dan Garwe (2010) hambatan dalam usaha kecil menengah berasal dari lingkungan internal dan eksternal. Hambatan internal pada UMKM "RDS" meliputi kemampuan manajerial serta lokasi dan jaringan sekitar tempat usaha dijalankan. Sedangkan hambatan eksternal meliputi hambatan finansial, ekonomi dan teknologi, kejahatan dan korupsi, infrastruktur, kompetisi, dan tenaga kerja.

Kemampuan manajerial diatur oleh adanya pengetahuan, kemampuan, kebiasaan, dan perilaku yang memberikan kontribusi terhadap efektivitas dari seseorang (Hellriegel, et al, 2008). Kemampuan manajerial ini digambarkan oleh pengetahuan pimpinan tentang kondisi pasar saat ini, pengalaman yang relevan untuk usaha, pengalaman sebelumnya dalam mengelola jenis usaha, pengalaman untuk menarik dan mempertahankan staf yang sesuai, dan pengalaman dalam manajemen usaha kecil. Berdasarkan observasi serta wawancara peneliti yang dilakukan pada UMKM "RDS", diketahui bahwa tidak ditemui hambatan terkait dengan indikator kemampuan manajerial. Hal tersebut dikarenakan Bapak Rudik (pimpinan UMKM "RDS") sangat mengetahui kondisi pasar (terutama terkait dengan produk tahu) salah satunya dapat diketahui dari inovasi beliau memproduksi tahu dengan menggunakan bahan baku kedelai organik yang mana produk tahu organik ini belum ada di pasaran. Selain itu, Bapak Rudik juga memiliki pengalaman bisnis tahu. Sebelum mendirikan UMKM "RDS" ini sebelumnya beliau sempat juga membuka usaha produksi tahu bersama temannya. Dengan pengalaman serta keahlian yang dimiliki, beliau dapat dikatakan bisa dengan mudah menarik dan mempertahankan karyawan yang sesuai serta memanajemen jalannya bisnis tahu "RDS" ini.Lokasi dan jaringan juga merupakan hambatan internal pada suatu usaha. Lokasi dan jaringan ini meliputi seberapa tinggi pengaruh lokasi yang ditempati sekarang ini serta jaringan responden terhadap lingkungan usaha. UMKM "RDS" bertempat di lokasi yang banyak terdapat pengusaha produksi tahu. Meskipun demikian UMKM RDS ini merupakan satu-satunya UMKM yang memproduksi tahu organik. Selain itu, UMKM "RDS" bisa dikatakan sudah menjadi UMKM di bidang produksi tahu organik yang terkenal. Penitian ini didukung dengan penelitian menurut Tjandra \& Ardianti (2013) Kemampuan manajerial sangat penting untuk bertahan dan bertumbuhnya suatu perusahaan kecil dan menengah yang baru. Kurangnya 
pengalaman manajerial dan kemampuan merupakan alasan utama gagalnya sebuah perusahaan baru.

Hambatan finansial merupakan salah satu hambatan eksternal yang seringkali terjadi dalam suatu usaha, khususnya usaha kecil dan menengah. Hambatan finansial ini dapat digambarkan dengan sulitnya memperoleh dana/modal produksi misalnya dari lembaga keuangan (bank). Berdasarkan dari observasi dan wawancara yang dilakukan peneliti, UMKM "RDS" ini pernah mengalami kesulitan dalam memperoleh dana untuk produksi. Pada awalnya, Bapak Rudik memulai usaha ini murni dari dana pribadi beliau yang diperoleh dari meminjam pada para tetangganya. Sehingga beliau memiliki tanggungan untuk mengembalikan uang tersebut kepada tetangganya. Penitian ini didukung dengan penelitian menurut Tjandra \& Ardianti (2013) Hambatan dalam segi finansial juga dikarenakan adanya kesulitan yang dialami oleh pengusaha mikro kecil, dalam peminjaman kredit di bank, karena kredibilitasnya yang kurang menjanjikan, mengakibatkan bank sulit untuk mengeluarkan pinjaman terhadap perusahaan mikro dan kecil ini.

Ekonomi dan teknologi juga merupakan indikator hambatan eksternal yang digambarkan dengan tidak stabilnya harga bahan baku, daya beli masyarakat terhadap produk terkait, dan kesulitan untuk mendapatkan peralatan produksi. Pada UMKM "RDS", meskipun harga bahan baku berupa kedelai organik cenderung mahal dan tidak stabil dibandingkan dengan harga kedelai biasa, hal tersebut tidak menjadi hambatan dalam usaha, ini dikarenakan tingkat daya beli masyarakat terhadap tahu organik milik UMKM "RDS" sangat bagus (berdasarkan wawancara dengan Bapak Rudik pada Maret 2017). Dengan daya beli masyarakat yang bagus tersebut, maka perputaran modal yang digunakan sekaligus keuntungan yang diterima dapat diperoleh dengan cepat. Sedangkan untuk peralatan produksi yang dibutuhkan, mayoritas alat yang dibutuhkan cukup mudah dicari, sehingga hal ini tidak menimbulkan hambatan dalam UMKM "RDS". Penitian ini didukung dengan penelitian menurut Tjandra \& Ardianti (2013) Investasi dalam teknologi dan mengikuti perkembangan IT, merupakan kepentingan bagi semua perusahaan. Teknologi memainkan peranan penting dalam proses bertumbuhnya suatu perusahaan kecil dan menengah baru, teknologi juga dapat memaksimalkan kesempatan dalam melakukan usaha. Variabel ekonomi termasuk didalamnya kebijakan fiskal dan kebijakan moneter dari pemerintah, inflasi, bunga bank, dan mata uang asing, variabel ini juga sangat mempengaruhi permintaan akan barang dan jasa, dan juga sangat berpengaruh terhadap pertumbuhan perusahaan.

Berdasarkan observasi dan wawancara yang telah dilakukan, diketahui bahwa lingkungan sekitar UMKM "RDS" ini cenderung aman dari tindak kriminalitas, selain itu, berdasarkan wawancara yang dilakukan diperoleh hasil bahwa pimpinan UMKM "RDS" tidak pernah dimintai pungutan liar dari phakpihak tertentu. Berdasarkan hal tersebut maka dapat disimpulkan bahwa UMKM "RDS" ini tidak mengalami hambatan terkait indikator kejahatan dan korupsi. Indikator hambatan eksternal pertumbuhan usaha selanjutnya adalah infrasturktur, kompetisi, dan tenaga kerja. Hambatan infrastruktur digambarkan oleh tingginya biaya listrik dan air, serta buruknya kondisi jalan. Pada UMKM "RDS" ini, harga listrik dan air yang dibebankan dianggap cukup murah oleh pimpinannya, serta kondisi jalan bisa dibilang cukup bagus. Selanjutnya, 
pimpinan UMKM "RDS" berpendapat bahwa produk tahu organik yang diproduksinya belum memiliki pesaing, karena UMKM "RDS" merupakan satu-satunya usaha yang memproduksi tahu organik. Sedangkan untuk tenaga kerja, beliau juga berpendapat bahwa selama ini tidak ada kesulitan dalam mencari tenaga kerja. Berdasarkan hal tersebut, maka dapat disimpulkan bahwa jalannya UMKM "RDS" ini tidak menemui hambatan pada indikator infrastruktur, kompetisi, dan tenaga kerja.

Berdasarkan penjelasan mengenai hambatan-hambatan pada UMKM "RDS" di atas, maka Bapak Rudik mempunyai upaya-upaya untuk mengatasi hambatan-hambatan pertumbuhan UMKM. Salah satu hambatan yang terjadi di UMKM "RDS" adalah dalam aspek finansial. Untuk mengatasi hambatan finansial tersebut Bapak Rudik melakukan penjadwalan finansial atau menata ulang finansial dengan maksud Pak Rudik memanajemen aliran dana pada UMKM "RDS" (seperti keluar masuknya uang) dan dari sanalah Bapak Rudik mengetahui dana yang dibutuhkan untuk menjalankan kegiatan bisnisnya, kemudian Bapak Rudik akan meminjam dana atau melakukan penarikan pada investor. Sedangkan indikator hambatan yang lain seperti kemampuan manajerial, lokasi dan jaringan, ekonomi dan teknologi, kejahatan dan korupsi, infrastruktur, kompetisi, dan tenaga kerja tidak terjadi di UMKM "RDS". Beberapa Indikator tersebut belum pernah menjadi hambatan dalam usaha Tahu "RDS". Satu-satunya hambatan yang pernah terjadi di usaha tersebut hanya hambatan finasial.

\section{SIMPULAN}

Kondisi entrepreneurial leadership yang dimiliki Bapak Rudik pimpinan UMKM Tahu "RDS" secara umum baik. Hubungan dengan para karyawan secara umum juga berjalan dengan baik. Penggunan model persedian EOQ menjadi salah satu faktor dalam peningkatan usaha Tahu RDS, model kepemimpinan visioner yang dimiliki oleh Bapak Rudik menjadikan usahanya terus berkembang dikarenakan inovasi-inovasi yang terus di lakukan.

Kepemimpinan Bapak Rudik juga memperhitungkan resiko dalam usahanya, penggunaan model ECM yang mampu memperhitungkan resiko yang akan terjadi dengan penggunaan informasi sebelumnya, sehingga resiko usaha yang mengakibatkan kerugian dapat di minimalisir atau diatasi dan usaha tetap berjalan dengan baik. Pendelegasian tugas yang jelas dan tepat serta pengawasan langsung menjadikan usaha berkembang dengan baik. Kekonsistenan usaha dan kemampuan dalam mengatasi hambatan usaha menjadi faktor penting dalam pengelolaan usaha, sehingga usaha Tahu "RDS" tetap berjalan dan tetap menjadi salah satu perusahaan tahu yang digemari masyarakat.

\section{DAFTAR RUJUKAN}

Darling, J., Keeffe, M., \& Ross, J. 2007. Entrepreneurial Leadership Strategies and Values: Keys toOperational Excellence. Journal of Small Businessand Entrepreneurship.16(2), 108-109. 
Fernald. et. al. 2005. A New Paradigm: Entrepreneurial Leadership. Southern Business review. College of Business Administration: Georgia Southern University. 30, 3-4.

Gupta et. al. 2010. Strategies For Initial Management Of Hypertension. Indian J Med Res.132(5): 531-542.

Gupta, V. dan MacMillan, I. (2004). Entrepreneurial Leadership: Developing a Cross-Cultural Construct.

Hellriegel D, Jackson SE, Slocum J, Staude G, Amos T, Klopper HP,Louw L, OosthuizenT (2008). Management. 2nd South Africa edition. Oxford University Press. Oxford.

Miles, M. B dan Huberman, A. M. 2007. Analisis Data Kualitatif: Buku sumber tentang metode-metode baru. Jakarta: Universitas Indonesia Press.

Myers, M.D. 2009. Qualitative Research in Business and Management. London: Sage Publications Ltd.

Olawale, F. dan Garwe, D. 2010. Obstacles to the Growth of New SMEs in South Africa: A Principal Component Analysis Approach. African Journal of Business Management, 4 (5) : 729-738.

Prakoso, B. 2005. Pengaruh Orientasi Pasar, Inovasi, dan Orientasi Pembelajaran mempengaruhi Kinerja Untuk Mencapai Keunggulan Bersaing. Jurnal Studi Manajemen \& Organisasi, 2 (1).

Robbins, S. P. dan Judge. 2008. Perilaku Organisasi. Jakarta: Salemba Empat.

Sarosa, S. 2012. Penelitian Kualitatif Dasar-Dasar. Jakarta: PT. Indeks

Surie, G., \& Ashley, A. 2008. Integrating Pragmatism and Ethics in Entrepreneurial Leadership for Sustainable Value Creation. Journal of Business Ethics, 81:235-246

Tambunan, T. 2012. Usaha Mikro Kecil dan Menengah di Indonesia: Isu-Isu Penting. Jakarta: LP3ES

Tjandra, R. R. dan Ardianti, R. 2013. Analisa Entrepreneurial Leadership dan Hambatan Pertumbuhan Usaha Mikro dan Kecil di Jawa Timur. AGORA, $1(3)$.

Undang-Undang Republik Indonesia Nomor 20 Tahun 2008 Tentang Usaha Mikro, Kecil, dan Menengah. 